\title{
Tattua
}

JOURNAL OF PHILOSOPHY

\section{GANDHI AND WHITEHEAD ON CONFLICT-SOLVING}

\author{
Helmut Maassen, Ph.D
}

The creation of the world - said Plato - is the victory of persuasion over force [...] Civilization is the maintenance of social order, by its own inherent persuasiveness as embodying the nobler altemative. The recourse to force, however unavoidable, is a disclosure of the failure of civilization, either in the general sociefy or in a remnant of individuals [...] Now the intercourse between individuals and between social groups takes one of these two forms: force or persuasion (Alfred North Whitehead, Adventures of ldeas 105).

For Whitehead, as for Gandhi, the major problem in conflict-solving was how to deal with force. Both had a clear notion that any real social progress would only be possible through persuasion. Similar notions of the interconnectedness of things are apparent. The notion of an "immanent transcendence", which provides the notion of peace, the final aim of all striving, is shared by both. Whitehead developed a metaphysics which allowed him to analyse conflict. Three types of conflict are possible for him: "a concept may conflict with a reality, or two realities may conflict, or two concepts may conflict" (MG 119). Obviously Gandhi was more of an activist than a systemic -thinker. Asked by Radhakrishnan about his philosophy, he said that it was up to people like Radhakrishnan and not him to "philosophize". Gandhi and Whitehead realized that dealing with coercive power, which is inevitable, was the major challenge to their concept of persuasion. They were realists enough to see that persuasion and coercion interplay in any human community, so coercion 
cannot be eliminated. Whitehead recognized that Gandhi came closest to the notion of persuasion in conflict solving as, he states in Adventures of Ideas:

[...] the religious spirit as an effective element in the affairs of men has just [April, 1931] obtoined one of its most signal triumphs. In India the forces of violence and strife, between rulers and people, between races, between religions, between social grades, - forces threatening to overwhelm with violence hundreds of millions of mankind - these forces have for the moment been halted by two men acting with the moral authority of religious conviction, the Mahatma Gandhi and the Viceroy of India [Lord Inwin] (Al 205).

\section{Whitehead's Philosophy on Conflict and Conflict Solving}

In Al, Whitehead describes the history of numerous conflicts of ideas in detail, e.g. in the development of theological doctrines, the conflicts of societies with each other or the conflict, arising from a novel idea e.g. equality and the role of women. Incidentally, one of the reasons why Whitehead left Cambridge was because, like Gandhi, he was an adamant advocate of the equality of women: the authorities did not allow female students into their colleges.

It is very clear for Whitehead that each society is confronted with power: coercive and persuasive power. Each society, from the very beginning, has to deal with certain forms of compulsion. 'We find civilized communifies struggling with two kinds of compulsion. There are the natural necessities, such as food, warmth, and shelter. There are also the necessities for a coordination of social activities. This coordination is produced partly by instinctive habit, sustained by flashes of good sense, partly by the compulsion exercised by other members of the community, and partly by reasonable persuasion' (Al 69).

Plato was the first thinker who described persuasion as a leading force towards progress in societies: 'More than two thousand years ago, the wisest of men proclaimed that the divine persuasion is the foundation of the order of the world, but that it could only produce such a measure of harmony as amid brute forces it was possible to accomplish. This, I suggest, is a plain anticipation by Plato of a doctrine of Grace, seven hundred years before the age of Pelagius and Augustine" (Al 205). Without the divine element of persuasion, there would be no creation; according to Whitehead. 'The creation of the world, said Plato, is the victory of persuasion over force. The worth of men consists in their liability to persuasion!' 
Leaving out the theological consequences of this statement here, let us focus our attention on the ethical aspect. Men can persuade and can be persuaded by the disclosure of alternatives, for better or worse. Civilization is the maintenance of social order by virtue of its own inherent persuasiveness as embodying the nobler alternative. The recourse to force, however unavoidable, is a disclosure of the failure of civilization, either in general society or in particular individuals. Thus, in a vibrant civilization, there is always an element of unrest, as sensitivity to ideas means curiosity, adventure, change. Civilized order survives on its merits and is transformed by its power to recognize its imperfections.

'The intercourse between individuals and between social groups takes one of two forms, force or persuasion. Commerce is the great example of intercourse in the way of persuasion. War, slavery, and governmental compulsion exemplify the reign of force' (Al 83). Whitehead concludes that the development of societies prove that those which allowed and provided most persuasion are the most advanced ones. The rule of men over women is according to him a 'Hang-over from barbarism' (Al 205).

Conflicts are necessary for social progress, because, without them, a society would end up as a stagnant entity. They are only necessary for progress, if they are taken as a challenge for creative advance, searching for a new contrast which increases intensity rather than fighting each other's values. As Isabella Palin puts it:

The ethical question is a question of enhancing the possibilities of coexistence of things that, at the given juncture, seem doomed to exclude one another - without by the same token embracing their pretensions to exclusive dominance, that is to say, without taking them "at face value". It is a question of undergoing the test of those clamouring voices in the urge for a better world.'

Conflict for Whitehead is a chance to advance towards a befter life and not as a necessary exclusion of one of the alternatives in question. 'The Interpretation to be achieved is a reconciliation of seeming incompatibilities. But these incompatibilities are not hypothetical. They are there on the stage of history, undoubted and claiming interpretation' (Al 170).

'The foundation of all understanding of sociological theory-that is to say, of all understanding of human life -is that no static maintenance of perfection is possible. This axiom is rooted in the nature of things. Advance or Decadence are the only

01. Palin, On the Conflict of Values, her MS p5. 
choices offered to mankind. The pure conservative is fighting against the essence of the universe. This doctrine requires justification. It is implicitly denied in the learned tradition derived from ancient thought. The doctrine is founded upon three metaphysical principles. One principle is that the very essence of real actualitythat is, of the completely real-is process. Thus each actual thing is only to be understood in terms of its becoming and perishing. There is no halt in which the actuality is just its static self, accidentally played upon by qualifications derived from the shiff of circumstances. The converse is the truth (Al 274-5).

The final aim of civilization is peace. Peace, though, is not just an absence of violence but a living experience of overcoming conflict through the novel advance into contrasts. 'Peace is not then a static state of affairs. It is an adventure of overcoming conflict through the construction of a novel coherence that enjoys support, not through a spread of domination. This means that war and peace are not distributed as rivalling options, and that it is assumed that in the desire to live better there is the desire for peace and the rejection of violence. ${ }^{2}$

The worth of men consists in their liabilify to persuasion. They can persuade and can be persuaded by the disclosure of alternatives, the better and the worse. Civilization is the maintenance of social order, by its own inherent persuasiveness as embodying the nobler alternative. The recourse to force, however, unavoidable, is a disclosure of the failure of civilization, either in the general society or in a remnant of individuals (Al 83). This "victory of persuasion" is never final; it is always a struggle of tolerance, untimely always in danger of its own suspension. Its creature - "the word of civilized order" (Al 25) - -is always endangered by its excluded (and exclusive) violence, the illusion of unconditioned self-creation. Therefore, civilizations are described by Whitehead in the following way: 'We have noted four factors which decisively govern the fate of social groups. First, there stands the inexorable law that apart from some transcendent aim the civilized life either wallows in pleasure or relapses slowly into a barren repetition with waning intensities of feeling. Secondly, there stands the iron compulsion of nature that the bodily necessities of food, clothing, and shelfer be provided. The rigid limits which are thereby set to modes of social existence can only be mitigated by the growth of an understanding by which the interplay between man and the rest of nature can be adjusted. Thirdly, the compulsory dominion of men over men has a double significance. It has a benign effect so far as it secures the coordination of behaviour necessary for social welfare. But it is fatal to extend this dominion beyond the barest limits necessary for this coordination. The progressive societies are those which most decis-ively have trusted themselves to the fourth factor which is the way of persuasion' (Al 85).

02. Palin, 12. 
This does not, of course, mean that one can find static forms or values which guarantee the progress in history. Quite the opposite: each sociely with its conflicts relies on the advance of novelty which allows itself to move from conflict to contrast. The delicate balance of order and novelty only grants a peaceful and not stale society.

The art of progress is to presene order amid change and to preserve change amid order [...]. What is required [...] is order entering upon novelty; so that the massiveness of order does not degenerate into mere repetition; and so that the novelty is always reflected upon a background of system. But the two elements must not really be disjoined. It belongs to the goodness of the world that its settled order should deal tenderly with the faint discordant light of the dawn of another age [...].The old dominance should be transformed into the firm foundations, upon which new feelings arise, drawing their infensities from delicacies of contrast between system and freshness. In either alternative of excess, whether the past be lost, or be dominant, the present is enfeebled. This is only an application of Aristotle's doctrine of the 'golden mean'(PR 339).

Given these metaphysical principles, one has to ask, whether they really suffice for a ethical or political theory? I think one clearly has to say, no, they don't suffice, but they don't have to as metaphysical principles; they cannot, if they are supposed to be meta principles. But, on the other hand, it might become clear what kind of political or moral action would follow. In this respect, Whitehead himself indicated that Gandhi was one person, whom he considered as acting according to the principles which he considered fundamental for social progress: persuasion.

$[\ldots]$ the religious spirit as an effective element in the affairs of men has just [April, 193]] obtained one of its most signal triumphs. In India the forces of violence and strife, between rulers and people, between races, between religions, between social grades, - forces threatening to overwhelm with violence hundreds of millions of mankind - these forces have for the moment been halted by two men acting with the moral authority of religious conviction, the Mahatma Gandhi and the Viceroy of India [Lord Inwin] (AI 205).

\section{Conflict and Conflict-Solving in Gandhi's Thought}

As mentioned above, Gandhi was a man of action and not a developer of philosophical systems. Bufl claim, nevertheless, that such a system can be found and formulated in Gandhi's opus of 100 Volumes of more than 500 pages each. 
Let me first iny to deconstruct some basic myths about Gandhi. It is not true that he refused the use of the 'sword' under all circumstances. A totally unexpected aspect of the development of Gandhi's theory of non-violence is the fact that he was willing to cooperate with the British in South Africa in 1899: he wore the British Army uniform (see picture ${ }^{3}$ ) and joined the voluntary ambulance unit in the AngloBoer war. This has been mentioned in the book 'Soldiering On', released by Sainik Samachar to mark its centenary year in 2009: "If Fate has decreed that we should fight a few battles among ourselves, let us. This will not be the first instance of such fighting in the annals of the world. Brothers sometimes fight with one another, but unite again. When the era of peace dawns upon us, wars will seem barbaric. Today, however, fighting is looked upon as civilized." ${ }^{4}$ f find it very important to recognize this in order to give due and full credit to Gandhiji's achievements.

1. Sketch of Gandhian Ethics: In a private conversation, one of Gandhi's Muslim associates and close friends in the fight for independence, Mr. Jamal Kidwai told me, when asked about specific problems in Gandhi's political, philosophical and religious thought: "My dear fellow, keep in mind, our first priority was to get rid of the British and not to develop political, philosophical or religious systems." Keeping this in mind and despite the fact that the Collected Works of Gandhi run into no less than 100 volumes, not counting the index volumes, it was a very active life and Gandhi never developed an ethics as such. But one can certainly find clear indications of what could be developed into an ethics. As Bhiku Parekh states: "Gandhi warned those who wanted to study his thought to take note of the time sequence in which his sayings found their place and, when in doubt, to look ut his later remarks rather than the earlier ones. This is because he was a strong believer in spiritual growth. ${ }^{25}$ Another criterion, which sometimes gets overlooked, is Gandhi's stress on reason. He states very clearly and emphatically the acid test of Reason': "Error, no matter however immemorial it may be, cannot derive sanctity, and even a Vedic text if it is inconsistent with morality, with injustice, will have to go by the board. ${ }^{\prime 6}$...he declined to be bound by any interpretation, however learned

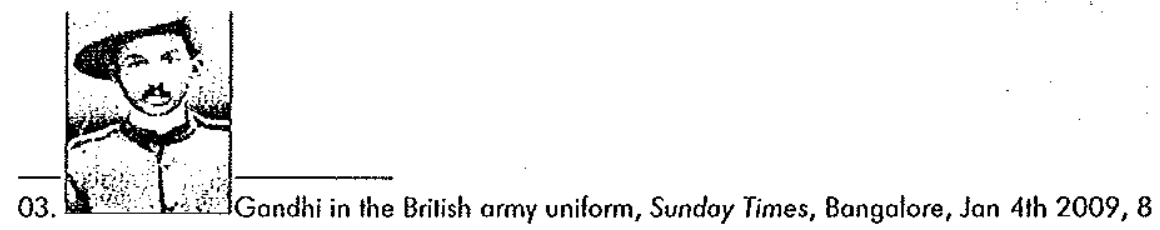

04. Vol. $33: 25$ September, 1925 - 10 February, 1926323 ; for an oulstanding onalysis of Gandhi's thought on State, Religion and Politics see (Conrad) and the preface by Jan Assmann, 9-22

05. Parekh, Gandhi's Political Philosophy, 70

06. (Chatteriee) p.29 (Desai Diory);(Chatterii), II 
it may be, if it were repugnant to reason or moral sense. ${ }^{7}$ For this approach on interpretation and the stress of experience of truth, Gandhi has been hailed as a postmodern thinker. ${ }^{8}$

2. Gandhi's concept of Human nature is basic for his Ethics. Concerning human nature, one should consider three fundamental aspects of Gandhi's thought:

2.1. Human nature is an integral part of the cosmos. For $G$ andhi, the cosmos was a well co-ordinated whole, whose parts were linked in a system of interdependence and mulual service, yojna. Gandhi liked to say that the cosmos is not structured like a pyramid, with the material world at the base and human beings the apex, but rather like a series of ever widening circles encompassing human kind, the sentient world, the material world and the all-including cosmos. The cosmic spirit infuses the universe and therefore even the material world is divine in nature. The whole universe taken as divine begs the question: can the human being be considered higher than other beings; what about the imminent fact that certain beings need other living beings as their food? Gandhi called the body the 'house of slaughter' and was deeply anguished by the violence it demanded. Human beings are necessarily interdependent. Each action of a human being not only has an effect on the other person, but also on the actor himself. As Gandhi would say, no man 'takes another down a pit without descending into it himself and sinning in the bargain'. Therefore, everybody has to take care for himsell, as he has to take care of the others. This is a concept which reminds one of Sartre's claims that, in acting by oneself, one is responsible for the world (a universal principle). This principle of indivisible humanity enabled Gandhi to crificize the oppression in South Africa as much as colonial rule in India. For example, in brutalizing the blacks the whites in South Africa were brutalizing themselves through that same act.

2.2. Human beings are four - dimensional beings. Unlike in the West, where, in general terms, a human being would be defined as a being with body and soul Gandhi considered a human being as four-dimensional: a) body, b) manas, c) âtman and d) swabhôva.

The human body makes the human being distinct and separate from everything else. This is the reason why the body nourishes the illusion that humans are individuals, in the sense that they are independent and not linked to other beings. The body is at the same time the house of the senses, which are like 'wild horses'.

07. (Chatteriee), 30

08. (Rudolph): Rudolph, lloyd I. Rudolph and Susonne Hoeber Rudolph. Postmodern Gandhi and Other Essays Gandhi and the World of Home, 3-59 
In addition to the body, the human being has a mind (manas). It includes chetana (stream of consciousness) and buddhi (intelligence). The manas is the seat of passion, thoughts, memory and moods. Chetana begins with birth and ends with death.

Alman is the spirit of the human being. The Alman is identical with the cosmic spirit. Thus all reality is divine 'in nature'. Atman, though, is not a thing or concept but an active force, which can be either enforced or blocked. If a human being is able to overcome all selfishness and illusions of independence, then that cosmic power can unfold in an unlimited manner. This is apparent in the English hymn which Gandhi liked most and which was framed in his Astram. If speaks of the suffering love of Jesus:

When I survey the wondrous cross On which the prince of glory $d y^{\prime} d$, My richest gain I count but loss, And pour contempt on all my pride.

Forbid it, Lord, that I should boast, Save in the death of Christ my God; All the vain things that charm me most, I sacrifice them to his blood.

See from his head, his hands, his feet, Sorrow and love flow mingled down; Did e'er such love and sorrow meet? Or thorns compose so rich a crown?

His dying crimson like a robe Spreads o'er his body on the tree, Then am I dead to all the globe, And all the globe is dead to me.

Where the whole realm of nature mine That were a present far too small; Love so amazing, so divine

Demands my soul, my life, my all. 9

09. Isaac Watts, 1674-1748, Hymn 7 (L.M.) Crucifixion to the World by the Cross of Christ, Gal VI, 14. I owe this reference to Lee Rouner. 
This monistic concept of reality is very much in accordance with the Advaita school of Indian thought. The question of Theodicy arises because of the inert cosmic presence of the divine spirit. As with all concepts of theodicy, Gandhi faces the problem of accounting for the origin and reality of evil, especially with social or political evil in the 20th century, such as the Holocaust and the World Wars.

If all nature is basically divine, one has to account for the individuality of different living beings, particularly for the apparent differences of human beings. Gandhi accounts for this through the concept of Swabhava. Swabhava, the moral and psychological constitution of a human being, is shaped by its different moral and psychological heritage, that is, the previous life/ or lives. The hypothesis is, that all human beings not only posses a physical body but a spiritual one, which survives the birth and death of an individual being, which is called sukshma sharira. Therefore, one should not speak of a transgression of the soul, but rather of the sukshma sharira.

2.3 The physical as much as the moral world function according to certain laws, the law of rebirth as well as the moral law, karma. The present state of the cosmic as the personal state is a result of earlier moral and cosmic states. Unlike the Christian doctrine, each individual has to live through circles of birth and rebirth, until it has finally become identical with the universal spirit and force. ${ }^{10}$

2.4 Satyagraha is certainly the best known ethico-practical concept of Gandhian thought, and rightly so, because a similar one, linking ethical consideration and practice has yet to be found. It avoids Weber's split of Gesinnungs und Verantwortungsethik and links virtue ethics with political philosophy. Gandhi developed the concept of Satyagraho in South Africa and then fransferred it to India.

He never wanted to abolish the Dharma concept and the Varna concept, though he fiercely tried to fight the concept of untouchability. The Varna or caste system provides an existing form for the interdependence and mutual responsibility of all human beings and should therefore not be abolished: "But dharma is not such a lifeless thing. Non-violence is a living force or power. No one has been or will ever be able to measure its limits or its extent. Non-violence means universal love, it implies compassion for all living beings and the resultant strength to sacrifice oneself. Since many mistakes may be made while this love expresses itself, we cannof give up the quest for the whole of this dharma. Even the mistakes committed

10. For a more detailed analysis of the human nature according to Gandhi, see (Parekh) 38-50 
while seeking the pure path take us a step forward in the quest. " requests by American and British bishops of an Infernational Missionary conference to reconsider his advice to the Czechs and German Jews a few weeks earlier to practise non-violence and commit mass suicide, because Mussolini and Hifler were totally immoral, Gandhi rejected the notion that any ruler was beyond moral regeneration. $^{12}$

\section{Critical Evaluation}

Gandhi's approach towards the Czech people or the Jews ${ }^{13}$ fails to apply his own principles of Salyagraha: the analysis of the opponent and the circumstances is missing totally. The bottom up strategy was one of the most important factors in Gandhi's strategy. Because he was a trained lawyer, he knew the British legal system and knew what a decisive role a mobilization of the masses in a democracy would play. He opplied the same principle to economics quite successfully. Transferred to the $21^{\text {st }}$ century, a bottom up economy would have to look quite different to what it did to Gandhi in the thirties of last century. A detailed analysis of the political, economic and social background is lacking in his speeches on Hitler, Germany, the Jews and World War Il. Had they contained such an analysis, they might have pointed to the same conclusion as he had earlier on: 'The very reasons that I have given you today for demanding complete control for the Army are also reasons for pleading for, for demanding, control over our External Affairs. ${ }^{14}$

Or, put differently: 'So it comes to this, that under exceptional circumstances, war may have to be resorted to as a necessary evil, even as the body is. If the motive is right, it may be furned to the profit of mankind and that an ahimsaist may not stand aside and look on with indifference but must make his choice and actively cooperate or actively resist. ${ }^{15}$

11. Vol. 43 : 10 September, 1928 - 14 January, 1929, 190

12. Cf. Judith M. Brown, Gandhi, Prisoner of Hope, New Haven 1989, 320. For details see Appendix 1 .

13. For a full documentotion see Gandhi, The Jews And Polestine, A Collection of Articles, Speeches, Letters and Interviews Compiled by: E. S. Reddy hilp://www.gandhiserve.org/ intormation/writings_online/arlicles/gandhi_iews_palestine.himl\#A\%20Lelter\%20 to\%20Gondhi,\%20by 20 Hayim\%20Greenberg,\%201937.

14. Vol.54: 13 October, 1931 - 8 February, 1932170

15. Vol. 17: 26 April, 1918 - April, 1919, 124. 


\section{Appendix I: Gandhi to the Czech People and the Jews}

In 1939 Gandhi wrote: "I want to speak to the Czechs because their plight moved me to the point of physical and mental distress and I felt that it would be cowardice on my part not to share with them the thoughts that were welling up within me. It is clear that the small nations must either come or be ready to come under the protection of the dictators or be a constant menace to the peace of Europe. In spite of all the goodwill in the world England and France cannot save them. Their intervention can only mean bloodshed and destruction such as has never been seen before. If I were a Czech, therefore, I would free these two nations from the obligation to defend my country. And yet I must live. I would not be a vassal to any nation or body. I must have absolute independence or perish. To seek to win in a clash of arms would be pure bravado. Not so, if in defying the might of one who would deprive me of my independence I refuse to obey his will and perish unarmed in the attempt. In so doing, though I lose the body, I save my soul, i.e., my honour. This inglorious peace should be my opportunity. I must live down the humiliation and gain real independence. But, says a comforter, 'Hitler knows no pity. Your spiritual effort will avail nothing before him. 'My answer is, 'You may be right. History has no record of a nation having adopted non-violent resistance. If Hitler is unaffected by my suffering, it does not matter. For I shall have lost nothing worth [preserving]. My honour is the only thing worth preserving. That is independent of Hitler's pity. But as a believer in non-violence, I may not limit its possibilities. Hitherto he and his likes have built upon their invariable experience that men yield to force. Unarmed men, women and children offering non-violent resistance without any bitterness in them will be a novel experience for them. Who can daresay that it is not in their nature to respond to the higher and finer forces? They have the same soul that I have. 'But says another comforter, 'What you say is all right for you. But how do you expect your people to respond to the novel call? They are trained to fight. In personal bravery they are second to none in the world. For you now to ask them to throw away their orms and be trained for non-violent resistance seems to me to be a vain atfempt. "You may be right. But I have a call I must answer. I must deliver my message to my people. This humiliation has sunk too deep in me to remain without an outlet. 1 , at least, must act up to the light that has downed on me. 'This is how I should, I believe, act if I was a Czech. When I first launched ouf on Satyagraha, I had no companion. We were thirteen 7thousand men, women and children against a whole nation capable of crushing the existence out of us. I did not know who would listen to me. It all came as in a flash. All the 13,000 did not fight. Many fell back. But the honour of the nation was saved. New history was written by the South African Satyagraha. A more apposite instance, perhaps, is that of Khan Saheb Abdul Ghaffar Khan, the servant of God as he calls himself, the pride of Afghans, as the Pathans delight to call him. He is sitting in front of me as 
I pen these lines. He has made several thousands of his people throw down their arms. He thinks he has imbibed the lesson of non-violence. He is not sure of his people. Elsewhere I reproduce the pledge that his soldiers of peace make. I have come to the Frontier Province; or rather he has brought me, to see with my own eyes what his men here are doing. I can say in advance and at once that these men know very little of non-violence. All the freasure they have on earth is their faith in their leader. I do not cite these soldiers of peace as at all a finished illustration. I cite them as an honest attempt being made by a soldier to convert fellow soldiers to the ways of peace. I can testify that it is an honest attempt, and whether in the end if succeeds or fails, it will have its lessons for salyagrahis of the future. My purpose will be fulfilled if I succeed in reaching these men's hearts and making them see that if their non-violence does not make them feel much braver than the possession of arms and the ability to use them they must give up their non-violence which is another name for cowardice, and resume their arms which there is nothing but their own will to prevent them from taking back. I present Dr. Benes with a weapon not of the weak but of the brave. There is no bravery greater than a resolute refusal to bend the knee to an earthly power, no matter how great, and that without bitterness of spirit and in the fullness of faith that the spirit alone tives, nothing else does." Nol. 74: 9 September, 1938-29 January, 1939, 90-92)

Equally controversial is the similar if not even stronger advice he gave to the German Jews: [...] If I were a Jew and were born in Germany and earned my livelihood there, I would claim Germany as my home even as the tallest gentile German may, and challenge him to shoot me or cast me in the dungeon; / would refuse to be expelled or to submit to discriminating treatment. And for doing this, 1 should not waif for the fellow Jews to join me in civil resistance but would have confidence that in the end the rest are bound to follow my example. If one Jew or all the Jews were to accept the prescription here offered, he or they cannot be worse off than now. And suffering voluntarily undergone will bring them an inner strength and joy which no number of resolutions of sympathy passed in the world outside Germany can. Indeed, even if Britain, France and America were to declare hosilitities against Germany, they can bring no inner joy, no inner strength. The calculated violence of Hitler may even result in a general massacre of the Jews by way of his first answer to the declaration of such hostilities. But if the Jewish mind could be prepared for voluntary suffering, even the massacre I have imagined could be furned into a day of thanksgiving and joy that Jehovah had wrought deliverance of the race even at the hands of the fyrant. For to the god fearing, death has no terror. It is a joyful sleep to be followed by a waking that would be all the more refreshing for the long sleep. It is hardly necessary for me to point out that it is easier for the Jews than for the Czechs to follow my prescription. And they have in the Indian satyograha campaign in South Africa an exact parallel. There the Indians occupied 
precisely the same place that the Jews occupy in Germany. The persecution had also a religious finge. President Kruger used to say that the white Christions were the chosen of God and Indians were inferior beings created to serve the whites. A fundamental clause in the Transvaal constitution was that there should be no equality between the white sand coloured races including Asiatics. There too the Indians were consigned to ghettos described as locations. The other disabilities were almost of the same type as those of the Jews in Germany. The Indians, a mere handful, resorted to Satyagraha without any backing from the world outside or the Indian Government. Indeed the British officials tried to dissuade the satyagrahis from their contemplated step. World opinion and the Indian Government came to their aid after eight years of fighting. And that too was by way of diplomatic pressure not of a threat of war. But the Jews of Germany can offer salyagraha under infinitely better auspices than the Indians of Soulh Africa. The Jews are a compact, homogeneous community in Germany. They are far more giffed than the Indians of South Africa. And they have organized world opinion behind them. I am convinced that if someone with courage and vision can arise among them to lead them in non-violent action, the winter of their despair can in the twinkling of an eye be furned into the summer of hope. And what has today become a degrading man-hunt can be furned into a calm and determined stand offered by unarmed men and women possessing the strength of suffering given to them by Jehovah. If will be then a truly religious resistance offered against the godless fury of dehumanized man. The German Jews will score a lasting victory over the German gentiles in the sense that they will have converted the latter to an appreciation of human dignity. They will have rendered service to fellow-Germans and proved their title to be the real Germans as against those who are today dragging, however unknowingly, the German name into the mire" (CWMG, Vol. 74: 9 September, 1938 - 29 January, 1939, 241/242).

\section{Appendix II: Gandhi on Violence}

If Fate has decreed that we should fight a few battles among ourselves, let us. This will not be the first instance of such fighting in the annals of the world. Brothers sometimes fight with one another, but unite again. When the era of peace dawns upon us, wars will seem barbaric. Today, however, fighting is looked upon as civilized. (Nol. 33: 25 September, 1925 - 10 February, 1926, 323)

Hindu-Muslim unity means unity between all the races that inhabit the fair land of ours. Is that programme unattainable by us? Is that programme undesirable? But I have admitted my incompetence. I have admitted that I have been found wanting as a physician prescribing a cure for this malady. I do not find that either the Hindus or the Mussalmans are ready to accept my cure and therefore I simply nowadays confine myself to a passing mention of this problem and content myself 
by saying that some day or other we Hindus and Mussalmans will have to come together if we want the deliverance of our country; and, if it is to be our lot that before we can come together, we must shed one another's blood then I say the sooner we do so the better it is for us. If we propose to break one another's head, let us do so in a manly way, let us not then shed crocodile tears; let us not ask for sympathy from any quarter if you do not propose to give any quarter. That is what I have to say about the Hindu-Muslim unity. (Vol.31: 22 March, 1925, 15; June, $1925,241)$

I do not in the least share their pessimism. The Hindu-Muslim quarrels are in a way, unknown to us, a fight for swaraj. Each party is conscious of its impending coming. Each wants to be found ready and fit for swaraj when it comes. Hindus think that they are physically weaker than the Mussalmans. The latter consider them-selves to be weak in educational and earthly equipment. They are now doing what all weak bodies have done hitherto. This fighting therefore, however untortunate it may be, is a sign of growth. It is like the Wars of the Roses. Out of it will rise a mighty nation. A better than the bloody way was opened out to us in 1920, but we could not assimilate it. But even a bloody way is better than utter helplessness and unmanliness. (Vol. 36: 8 July, 1926 - 10 November, 1926, 269)

We are so very much fear-stricken that a severance of the British connection means to us violence and chaos. Well, I want to make myself clear once more. Votary as I am of non-violence, if I was given a choice between being a helpless witness to chaos and perpetual slavery, I should unhesitatingly say that I would far rather be witness to chaos in India, I would far rother be witness to Hindus and Mussalmans doing one another to death than that I should daily witness our gilded slavery. To my mind golden shackles are far worse than iron ones, for one easily feels the irksome and galling nature of the latter and is prone to forget the former. If therefore India must be in chains, I would they were of iron rather than of gold or other precious metals. Nol. 48: 21 November, 1929 - 2 April, 1930, 219)

Thus writes Sjt. Trivikramrav, a Bezwada barrister: Some others have also written much in the same fashion. I must admit my many inconsistencies. But since lam called 'Mahatma', I might well endorse Emerson's saying that 'foolish consistency is the hobgoblin of little minds'. There is, I fancy, a method in my inconsistencies. In my opinion there is a consistency running through my seeming inconsistencies, as in nature there is a unity running through seeming diversity. (Nol. 48: 21 November, 1929 - 2 April, 1930, 314)

I should be sorry, indeed, if responsible Mussalmans will not see the obvious corollaries of non-violence. In my opinion the fight is as religious with Hindus as 
with Mussalmans. I agree that ours is a spiritual jehad. But a jehad has, like all other wars, its strict restrictions and limitations. The Hindus and Mussalmans sail in the same boat. (Nol. 26: 24 January, 1922 - 12 November, 1923, 298)

The Muslim League may call Hindus names and declare India to be Dar-ul-Harb, where the law of jehad operates and all Muslims who co-operate with the Congress are Quislings fit only to be exterminated. But we must not cease to aspire, in spite of this wild talk, to befriend all Mussalmans and hold them fast as prisoners of our love. It would be a present possibility if Hindus in their lakhs offered themselves to be cut to pieces without retaliation or anger in their hearts. Non-violence is today rightly laughed out of court as Utopian. Nevertheless, I maintain that it is the only way to keep Hinduism alive and India undivided. Nol. 92: 9 August, 1946 - 6 November, 1946228/9)

The most excellent jehad is that for the conquest of self. Nol. 93: 7 November, 1946 - 16 February, 1947 303)

But we are not fighting a jehad just now. Gandhiji has shown us another path, and we know very well that in the present circumstances we shall not succeed in saving Islam by declaring a jehad; we do not have the strength for it. Gandhiij has shown us the way of non-co-operation, and we have accepted it. There are specific injunctions in the Koran supporting this. Even the Prophet had resort to non-cooperation for thirfeen years. As I have put my foith in Gandhili, quite a few Muslims are angry with me, but I can say that they do not understand me at all. I prefer the friendship of the Hindus to that of the Kafirs who have threatened the existence of Islam, and, for their sake, I consider it my duty to spare the cow. The Prophet himself had joined hands with idolators. So long as the Khilatat Committee and the aalims have not declared a jehad, we cannot draw the sword, and it is for this reason that I feel pained at Mr. Willoughby's murder. Had I known beforehand, I would have taken steps to prevent it. But to say this and express one's disapproval of the murder is one thing, and to declare that the murderer will go to hell is another. Only God can decide whether the murderer should go to hell or to heaven. All that we can say is that the assassination has given a set-back, to the Khilafat struggle and that we should prevent such acts. Nol. 21: 21 July, 1920 - 21 November, 1920 446)

I at least cannot possibly think that we have got responsible government without control of the Army, and therefore I feel deep down at the bottom of my heart that if we are to have responsible government-and the Congress wants responsible government, the Congress has faith in itself, in the masses of the people, and in all those brave military races, and what is more, the Congress has faith also in 
Englishmen someday doing their duty and transferring complete control to us-we must infect the British with that love for India which would enable her to stand on her own feet. Nol.54: 13 October, 1931 - 8 February, 1932169

The very reasons that I have given you today for demanding complete control for the Army are also reasons for pleading for, for demanding, control over our External Affairs.(Nol.54: 13 October, 1931 - 8 February, 1932 170)

Discussion with C.F.Andrews pacifism: There is not a single recruiting speech in which I have not laid the greatest stress upon this part of a warrior's duty. There is no speech in which I have yet said," Let us go to kill the Germans." My refrain is, "Let us go and die for the sake of India and the Empire", and I feel that, supposing that the response to my call is overwhelming and we all go to France and turn the scales against the Germans, India will then have a claim to be heard and she may then dictate a peace that will last. Suppose further that I have succeeded in raising an army of fearless men, they fill the trenches and with hearts of love lay down their guns and challenge the Germans to shoot them - their fellow men-I say that even the German heart will melt. I refuse to credit it with exclusive fiendishness. So it comes to this, that under exceptional circumstances, war may have to be resorted to as a necessary evil, even as the body is. If the motive is right, it may be furned to the profit of mankind and that an ahimsaist may not stand aside and look on with indifference but must make his choice and actively co-operate or actively resist. Nol. 17: 26 April, 1918 - April, 1919123-4).

During a prayer speech: "If we had the atom bomb, we would have used it against the British." - June 16, 1947 (Reference: Gandhi's "The Last Phase", Vol II, p. 326)

\section{References:}

01. Brown, Judith M. Gandhi Prisoner of Hope. New Hoven and London: Yale University Press, 1989.

02. Choltenjee, Margoret. Gandhi's Religious Thought. London: The Macmillon Press, 1983.

03. Chatterii, P.C. Secualr Values for secular India. New Delhi: Manohar, 1995.

04. Conrad, Dieter. Gandhi und der Begriff des Politischen Staat, Religion und Gewalt. Hrsg. Barbara Conrad-Lült. Mit einer Einführung von Jan Assmann. München: Wilhelm Fink Verlag, 2006.

05. CWMG: Gandhi, Mohandas Karamchand. The Collected Works of Mahaima Gandhi (Electronic Book). 98 Bde. New Delhi: Publications Division Government of India, 1999.

06. Porekh, Bhikhu. Gandhi. Oxford, New York: Oxforf University Press, 1997. 
07. Parekh, Bhikhu. Gandhi's Polifical Philosophy: A Critical Examination. London: Macmillan, 1989.

08. Reddy, E. S. Gandhi, "The Jews and Palestine, A Collection of Articles, Speeches, Letters and Interviews". http://www.gandhiserve.org/information/writings_online/articles/ gandhi jews palestine. html $\# A \% 20$ letter $\% 20$ to $\% 20$ Gondhi, $\% 20$ by $\% 20 \mathrm{Hoyim} \% 20$ Greenberg, $\% 201937$, kein Datum.

09. Rudolph, Lloyd I. and Susanne Hoeber Rudolph. Postmodern Gandhi and Other Essays Gondhi and the World at Home. Chicago and London: The University of Chicago Press, 2006.

10. Whitehead, Alfred North. Adventures of Ideas. New York: The Free Press; 1967 (1933).

11. Whitehead, Alfred North. "Mathematics and the Good." Essays in Science and Philosophy. New York: Greenwood Press, 1968.97-113.

12. PR: Process and Reality: An Essay in Cosmology. Ed. By D. R. Griffin/D. W. Sherburne. New York: The Free Press, 1978 (1929). 